\title{
The Effect of Concept Map on Academic Achievement of Thinking and Media Literacy Course
}

\section{El efecto del mapa conceptual sobre el logro académico del pen- samiento y el curso de alfabetización mediática}

\author{
Nabiollah Malekzadeh \\ Islamic Azad University, Kazerun, Iran. \\ ORCID: https://orcid.org/0000-0002-8631-0944 \\ Alireza Ghasemizad* \\ Islamic Azad University, Kazerun, Iran. \\ ORCID: https://orcid.org/0000-0002-6565-9856 \\ Abdolmohammad Taheri \\ Islamic Azad University, Shiraz, Iran. \\ ORCID: https://orcid.org/0000-0001-8988-0638

\section{Pari Mashayekh} \\ Islamic Azad University, Kazerun, Iran. \\ ORCID: https://orcid.org/0000-0001-5469-9425
}

Received 06-14-20 Revised 08-10-20 Accepted 09-01-20 On line 09-30-20

*Correspondence

Email: alirezaghasemizad@gmail.com
Cite as:

\footnotetext{
Malekzadeh N. Ghasemizad A. Taheri A. \& Mashayekh P. (2020). The Effect of Concept Map on Academic Achievement of Thinking and Media Literacy Course. Propósitos y Representaciones, 8 (SPE3), $\quad$ e762. Doi: http://dx.doi.org/10.20511/pyr2020.v8nSPE3.762
} 


\section{Summary}

This paper aimed to study the effect of education based on concept map on the academic achievement of secondary school male students in the field of thinking and media literacy. Quasi-experimental research method was used with experimental and control groups. Three classrooms were selected by purposive sampling method (one concept map presentation class, one concept map presentation and construction class and one control class) by random arrangement. In the group of presentation and construction (combined), the course materials were presented to the learners in the form of a concept map. The experimental groups were trained separately for 8 sessions by the teacher-made and combined concept map method and the control group was trained by the traditional method. All groups completed the teacher-made test of academic achievement at two levels of knowledge and perception (understanding). The measuring instrument validity using S. H. Lawshe formula was 0.79 and the reliability of this instrument was 0.807 using Kuder-Richardson. Findings of covariance analysis showed that the mean scores of post-tests of all three groups increased in compared to the pre-tests, but the most effect was observed in the presentation and construction of concept man (combined) group and the least effect was in the control group. Therefore, teaching by a concept map has led to an increase in students' scores.

Keywords: Concept Map, Academic Achievement, Meaningful Learning, Presentation and Construction of Concept Map.

\section{Resumen}

Este documento tuvo como objetivo estudiar el efecto de la educación basada en el mapa conceptual sobre el rendimiento académico de los estudiantes varones de secundaria en el campo del pensamiento y la alfabetización mediática. Se utilizó un método de investigación cuasiexperimental con grupos experimentales y de control. Se seleccionaron tres aulas mediante un método de muestreo intencional (una clase de presentación de mapa conceptual, una clase de presentación y construcción de mapa conceptual y una clase de control) por disposición aleatoria. En el grupo de presentación y construcción (combinado), los materiales del curso se presentaron a los alumnos en forma de un mapa conceptual. Los grupos experimentales fueron entrenados por separado durante 8 sesiones por el método de mapa conceptual combinado y hecho por el maestro y el grupo de control fue entrenado por el método tradicional. Todos los grupos completaron la prueba de rendimiento académico realizada por el maestro en dos niveles de conocimiento y percepción (comprensión). La validez del instrumento de medición con la fórmula de S. H. Lawshe fue de 0,79 y la confiabilidad de este instrumento fue de 0,807 con Kuder-Richardson. Los resultados del análisis de covarianza mostraron que las puntuaciones medias de las pruebas posteriores de los tres grupos aumentaron en comparación con las pruebas previas, pero el mayor efecto se observó en la presentación y construcción del grupo de concepto (combinado) y el menor efecto fue en El grupo de control. Por lo tanto, la enseñanza mediante un mapa conceptual ha llevado a un aumento en los puntajes de los estudiantes.

Palabras clave: Mapa conceptual, logro académico, aprendizaje significativo, presentación y construcción del mapa conceptual.

\section{Introduction}

The growth and development of each society depends on the education system of that society and the level of scientific and practical capability of the students in the future. Accordingly, every year countries spend significant amounts of their national income on education, but some factors lead to a waste of a significant part of investments, which in investigating the causes of this phenomenon, research shows that needs, beliefs, desires and talents of students are the reasons 
(Zeinalipour et al., 2009), quoted from the Dolati Miandoab, (Fajonyomi, 2002). The process of teaching and learning is one of the most important factors affecting the education and motivation of students. Educational specialists are inventing new teaching and learning methods every day and we are seeing a change in direct learning strategies with the advancement of technology. However, in many cases, the teaching-learning process does not have a good quality and is indicated by several factors such as academic failure, lack of academic motivation, test anxiety and education regardless of context (Chen et al., 2019). One of the indicators of success of the education system is the index of academic achievement (Erkman et al., 2010). Therefore, the education system can be successful and efficient when the academic achievement of its learners has the highest grades in different courses. One of the most important concerns of teachers, education officials and students themselves is academic failure and academic achievement (Neuman \& Guterman, 2016). Academic achievement means the growth of learning curriculum that is measured by standardized or teacher-made tests (Feldman \& Kubota, 2015). Academic achievement is not only affected by knowledge structures and information processing methods, but also by motivational factors such as beliefs, attitudes and teaching methods of teachers (Safarzadeh Saharroomarashian, 2015). Today, education is not passive and aimless, but it is a purposeful activity to promote learning (Bolin et al., 2017).

Concept maps are usually produced in a hierarchical manner, that is, more general and comprehensive content is placed at the top level and near the bottom, the concepts and contents are more detailed (Martin, 1994). In this section, an example of a concept map is presented (Figure 1).

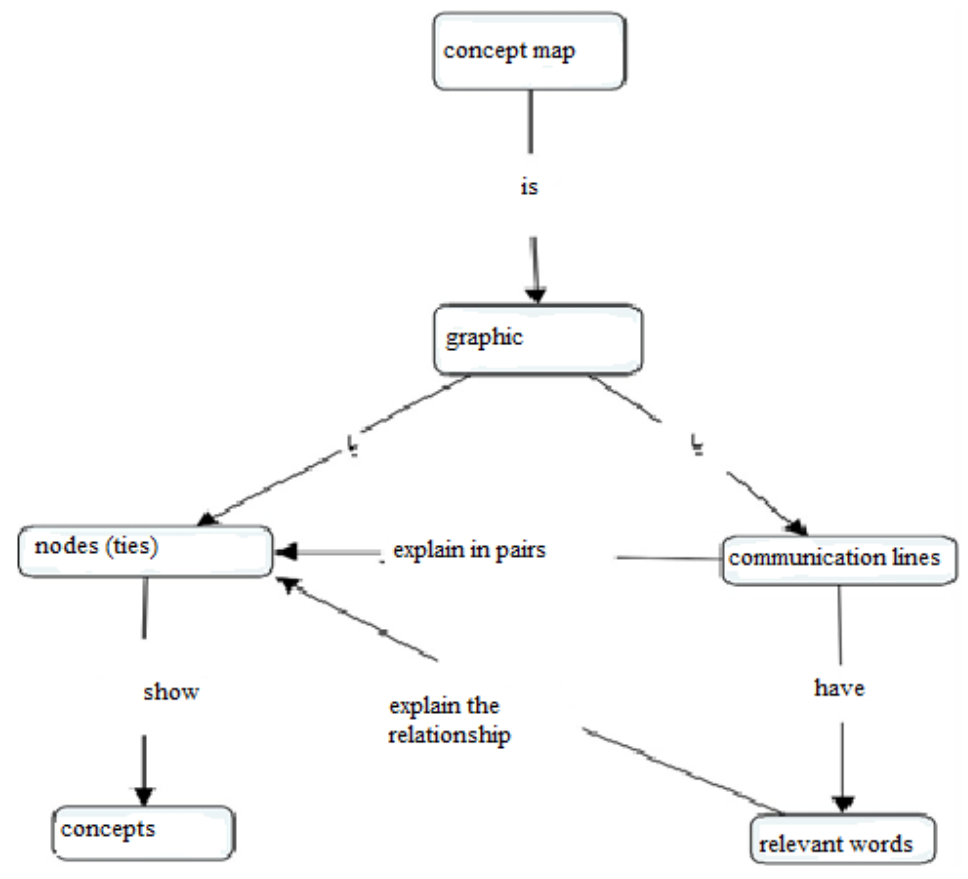

Figure 1. An Example of a Concept Map

Concept map-based curricula have many benefits over conventional curricula. By applying these kinds of curricula students' scores on academic achievement tests will increase (Fraser \& Edwards, 1985). Some teachers use concept maps as an educational strategy to create deeper learning in learners. A concept map allows past experience and understanding to be considered when forming a new concept within a conceptual framework. Concept maps are also used in various disciplines as methods of subject presentation. They are good ways to organize related 
information to a topic. Concept maps show both teachers and students to focus on a number of key ideas when working on learning assignments (Mesrabadi et al., 2005).

Research findings show that pupils and students use meaningful learning methods to a small extent. (Cañas \& Novak, 2007) in a study examined the learning patterns of American Cornell students and concluded that most students spend most of their time on non-meaningful learning. Concept map can be an effective way to increase learners' meaningful learning (Okebukola \& Jegede, 1989).

About the importance of using a concept map, it can be said that constructivism theory is one of the important frameworks that plays an important role in shaping and guiding reviews and educational activities. Although there may be different forms of constructivism, constructivism in general emphasizes that individuals actively build knowledge, and in the construction process, social interactions between individuals are also essential (Tsai, 2000). Therefore, in this view, in encouraging students to rely on their personal activities in learning the material, prior knowledge is considered and sometimes even criticized, and interaction between students and the teacher is easy; Therefore, in constructivist learning environments, students engage in meaningful learning and high-level intellectual skills. At the same time, teachers and learners can benefit from the use of conceptual diagrams based on constructivist perspectives as an educational-learning strategy (MEsrabadi et al., 2009).

The results of most studies on the use of students to prepare a group map have indicated that when group members prepare a concept map during a group discussion, meaningful learning among group members is increased.

Chularut and DeBacker defined concept map as a means of expressing relationships between concepts in a coherent and organized way.

(Muijs \& Reynolds, 2005), in the "Effective Teaching" book, introduced concept map as an effective educational strategy through which a structure of content can be created in the minds of learners. Since scientific concepts are unorganized, the teacher should use new and organized methods to teach scientific concepts, not just preparing a scattered list of scientific content and contents, and it should be said that the concept map method is appropriate to achieve the goal (organizing content) (Fellows, 1994).

In summary, research in the field of concept map has shown that teaching with the help of concept map increases learning, retention and retrieval of information and this increases academic achievement (Taei, 2014) and (Ghanbari, 2014) and (Ashuri et al., 2014) and (MEsrabadi et al., 2009) and (Jegede \& Alaiyemola, 1990) and (Baldan et al., 2010) and (Novak \& Canas, 2008) and (Kardan et al., 2015) and (Lee \& Nelson, 2005) and (Hall \& Donnell, 1996).

In this research, an attempt is made to compare the methods of teaching concept map with the traditional method, which is a passive method. In fact, traditional teaching methods, such as teacher-centered classes, are very difficult and costly for in-depth and sustainable teaching and a large number of learners. In conclusion, research on traditional methods has shown that this method is less effective than active methods (Jouzayi \& Sadi pour, 2013) and (Kardan et al., 2015) and (Beck, 2008) and (Mesrabadi et al., 2005) and (Lee \& Nelson, 2005).

In summary, research in the field of concept maps has shown that teaching (education) with the help of concept maps increases learning, retention and retrieval of information, and this increases meaningful learning and academic achievement (Ghanbari, 2014) and (Ashuri et al., 2014) and (Mesrabadi et al., 2005) and (Collins \& Robert, 2020) and (Chen et al., 2019) and (Watson \& Barrella, 2016) and (Jegede \& Alaiyemola, 1990) and (Novak \& Canas, 2008) and (Mesrabadi et al., 2009) and (Hall \& Donnell, 1996). 
The course of thinking and media literacy is one of the most important and necessary courses for learners of science in all academic courses, which due to its wide application throughout life can be considered as one of the fields of research in educational sciences. Therefore, its learning in a meaningful way seems necessary.

Furthermore, due to the weakness of learners in this field in a practical way during their studies and life, it is necessary to change the method of conveying its concepts and contents in a meaningful way to students. Therefore, in educational activities, it should be believed that the purpose of education was not merely to convey scientific facts; rather, there should be an opportunity to lead meaningful learning to learners. In addition, despite strong theoretical foundations such as Ausuble meaningful learning and constructivism approach in our country, a few activities have has been done to teach the topics of thinking and media literacy. So in this study, an attempt has been made to answer the question whether the use of concept maps in the process of teaching and learning the course of thinking and media literacy in the second year of high school is effective?

\section{Research Hypotheses}

1. The method of teaching a combined concept map (teacher-made and student-made) has a greater impact on students' academic achievement in thinking and media literacy than teachermade.

2. Using the concept map teaching method has a greater impact on students' academic achievement in thinking and media literacy than the traditional method or lecture.

\section{Materials and Methods}

The research design of the present study was a quasi-experimental design with pre-test and posttest and a comparison group. The statistical population was all male students in the tenth grade of high school in district one of Shiraz during 2018-2019, whose number is 3496 individuals. In this study, due to the limitations of research in terms of special conditions for controlling influential variables, administrative issues, satisfaction of subjects and the need to keep the effects of the teacher constantly, purposive nonprobability sampling method was used. In this method of sampling, the researcher, based on his knowledge of the characteristics of the community, in a non-probable manner selected 3 pre-formed classrooms that 61 students were studying in these classes. Then, in a random arrangement to teach a class by combined method map method (presentation and construction of concept map), a class by teacher-made concept map method and a class by conventional method (traditional) in the form of two experimental groups and a control group are considered.

In this study, in order to maximize the homogenization of the experimental and control classes, all three groups were located in the same school and one teacher taught in all three classes. Furthermore, the mean scores of the subjects in each group were examined and there was no significant difference between the means of the groups. A single research method was used to control teacher-related characteristics such as teaching abilities, motivation methods, and willingness to cooperate. Then, due to the similarity of the teacher, an effort has been made for all three groups to have the same conditions in terms of education. Researcher-made academic achievement test was also used to measure academic achievement.

Academic achievement test: Teacher-made academic achievement test was used to measure the cognitive interval. Students' level of knowledge and comprehension was measured above Bloom using the test. Academic achievement test from the content of chapter one to the beginning of chapter 5 of the book of thinking and media literacy of the tenth grade of high school in 
different levels of Bloom's cognitive domain in two parts of knowledge level and level of understanding was prepared by three experienced teachers.

Content validity was used to determine the validity of the academic achievement test. To determine the content validity of the test by the method of S.H. Lawshe, the judgment of experts on the extent to which test questions represent the content and objectives of the program was used and its value was 0.78 . In this study, to determine the reliability of the test, 20 students from other classes who had already passed this course were tested and the reliability of the test was calculated by Kuder-Richardson 20 method (suitable method for four-choice tests) as 0.807 . This value was obtained after the test of 0.791 .

Teacher-made concept map: The concept maps that were used to be presented in the experimental group classes by considering all the conditions for preparing a good concept map and in consultation with the teachers from the contents of the chapters of the thinking and media literacy book. Prepared Maps in different parts of the teaching, such as the pre-training stages (as a pre-organizing tool), the training stage (as a content presentation tool) and the post-training stage (as a lesson summary tool) were used.

Methods of applying research: In this study, the subjects participated in two experimental groups (a combined concept map class and a teacher-made concept map class) and a control group. The implementation details of the research process are presented in the following steps:

a. Preparation stage: In this stage, preparations for experimental application were provided. After identifying the examples, the necessary coordination was done and the textbooks were identified and concept maps were prepared for these textbooks with the help of the researcher and educational colleagues. Then, during two sessions of the pilot classes, the teacher received the necessary training regarding the goals of the project and how to teach based on the concept map to implement the mentioned method with the necessary preparation and awareness.

b. Concept map development stage for textbooks: Also in this stage for the textbook using Cmap Tools software version 6.8 onwards, concept maps were prepared and reviewed by the researcher and three experienced teachers of media thinking and literacy.

c. Implementation stage: The present study was performed in 8 sessions of 90 minutes in the experimental group classes. During these sessions, learners in one presentation group, one presentation and construction group (combined) and one control group were taught the same educational material simultaneously but in different ways. The details of the implementation in the experimental groups are as follows: In the experimental group, before presenting the teaching of the desired learning unit, the teacher placed a concept map poster next to the board and used it regularly in all stages of the teaching. The teacher first asked the learners to look at the concept maps to create a background of the subject in mind. The teacher then summarized the topics with reference to a concept map. At this stage, during the teaching, the maps were used as a tool for presenting the content, and after the explanations, the position of the presented materials and its relationship with other contents in the maps was indicated. After the training, concept maps were used as a tool to summarize the lesson. In the combined experiment group, in addition to all the steps described in the presentation group, after the end of the lesson, students were asked to draw the taught material individually and in groups on a piece of paper in the form of a concept map. Furthermore, before drawing a concept map, learners were taught how to prepare it.

Test implementation stage: In this stage, after the end of the training (teaching), the experimental and control groups performed the test without knowing about the test. 


\section{Results}

To investigate the research question whether there is a significant difference in students' academic achievement scores between the construction and concept map presentation group, the concept map presentation group and the control group while the pre-test scores are controlled, the method of covariance analysis was used. In terms of descriptive indicators, students' scores in the pre-test and post-test stages were compared between the three groups. (Table 1) shows the data of all three groups in the pre-test and post-test stages.

As it can be seen in (Table 1), there is no significant difference in pre-test between three groups but there is a difference between the post-test mean scores of the three groups.

Before analyzing the research hypotheses by univariate covariance analysis, its hypotheses were evaluated. The results of the Kolmogorov-Smirnov test confirmed the assumption that the data were normal. In addition, the results of $M$ box test and Levene test confirmed the assumption of equality of covariance matrices and the equality of variance of dependent variables.

\section{Table 1.}

Mean and Standard Deviation of Pre-test and Post-test of Academic Achievement of Experimental and Control Groups

\begin{tabular}{lcllllll}
\hline Groups & Number & \multicolumn{2}{l}{ Academic achievement } \\
\cline { 3 - 8 } & & & \multicolumn{2}{l}{ Pre-test } & \multicolumn{3}{c}{ Post-test } \\
\cline { 3 - 8 } & & Mean & $\begin{array}{l}\text { Standard } \\
\text { deviation }\end{array}$ & $\begin{array}{l}\text { Standard } \\
\text { error of the } \\
\text { mean }\end{array}$ & Mean & $\begin{array}{l}\text { Standard } \\
\text { deviation }\end{array}$ & $\begin{array}{l}\text { Standard } \\
\text { error of } \\
\text { the mean }\end{array}$ \\
\hline Combined & 20 & 7.8 & 1.196 & 0.267 & 35.10 & 2.381 & 0.374 \\
\hline $\begin{array}{l}\text { Teacher- } \\
\text { made }\end{array}$ & 20 & 7.50 & 1.357 & 0.303 & 30.52 & 2.314 & 0.377 \\
\hline Control & 21 & 8.00 & 1.224 & 0.267 & 27.52 & 1.513 & 0.367 \\
\hline
\end{tabular}

In (Table 1), the mean and standard deviation for all studied variables and samples in the pre-test and post-test are presented.

According to the findings of (Table 1), there is no significant difference between the mean of pre-test scores of the experimental and control groups; That is, the groups were homogeneous before the implementation of the teaching method. By considering the mean scores of the groups' post-test, it can be said that first the mean of the combined concept map is higher than the other two groups and then the mean of the teacher-made concept map is greater than the traditional group. Also in (Table 2), the results of multivariate test for the effectiveness of the independent variable on the dependent variable are presented. 
Table 2.

The Results of Multivariate Test

\begin{tabular}{|c|c|c|c|c|c|c|c|}
\hline $\begin{array}{l}\text { Effect } \\
\text { (trace) }\end{array}$ & Tests & $\begin{array}{l}\text { Value } \\
\text { criteria }\end{array}$ & $\mathrm{F}$ & $\begin{array}{l}\text { Hypothesis } \\
\text { freedom } \\
\text { degree }\end{array}$ & $\begin{array}{l}\text { Freedom } \\
\text { degree of } \\
\text { error distri- } \\
\text { bution }\end{array}$ & $\begin{array}{l}\text { Significance } \\
\text { level }\end{array}$ & $\begin{array}{l}\text { Shared } \\
\text { eta val- } \\
\text { ues }\end{array}$ \\
\hline
\end{tabular}

\begin{tabular}{llllllll}
\hline $\begin{array}{l}\text { Teaching } \\
\text { methods }\end{array}$ & Pillai & 8.98 & 15.218 & 6 & 112.000 & 00.1 & 4.49 \\
\cline { 2 - 8 } & $\begin{array}{l}\text { Wilk's } \\
\text { Lambda }\end{array}$ & 1.82 & 24.637 & 6 & 110.000 & 00.1 & 5.73 \\
\cline { 2 - 8 } & & & & & & \\
\hline & Hotelling & 4.053 & 36.475 & 6 & 108.000 & 00.1 & 6.70 \\
\cline { 2 - 7 } & $\begin{array}{l}\text { Roy's } \\
\text { largest } \\
\text { root }\end{array}$ & 3.941 & 63.941 & 3 & 56.000 & 00.1 & 7.98 \\
\end{tabular}

According to the findings of (Table 2), it can be argued that the independent variable in all four tests was effective on the dependent variable. According to the results, the Mbox and Levene tests confirm the assumption of equality of covariance and variance matrices. We can also determine from the eta square value of the Wilkes lambda trace test $(0.573)$ that the independent variable determines more than $57 \%$ of the total variance.

Due to the significance of the results of the multivariate table, it can be concluded that there is a significant difference between teaching methods. Now, LSD post hoc test was used to determine which groups have a significant difference in terms of academic achievement variable.

According to (Table 3), there is a significant difference between the methods of presenting the conceptual and combined map (presentation and student-made) with each other and each with the traditional method. The results of (Table 3) can be explained in 3 hypotheses: The first hypothesis is the teaching method of combined conceptual map (teacher-made and studentmade) has a greater effect on learners' learning in media thinking and literacy than teachermade. The difference between the mean of 4.54 and the significance level $(p<0.05)$ confirms this hypothesis. In the second hypothesis, the method of teaching a concept map in a combined In comparison with the traditional group increases the academic achievement of learners. The difference of the mean of 7.54 and the level of significance $(\mathrm{p}<0.05)$ confirms this hypothesis. The highest mean difference was observed between the combined and traditional groups. In the third hypothesis, the teaching method of the teacher-made concept map has a greater effect on the students' academic achievement in the course of thinking and media literacy than the traditional teaching method. The mean difference of 2.99 and the significance level $(\mathrm{p}<0.05)$ confirms this hypothesis. 
Table 3.

The Results of LSD Post Hoc Test of Academic Achievement Variable

\begin{tabular}{lllll}
\hline $\begin{array}{l}\text { Experimental } \\
\text { groups (i) }\end{array}$ & Groups (j) & $\begin{array}{l}\text { Mean difference } \\
(\mathrm{i}-\mathrm{j})\end{array}$ & $\begin{array}{l}\text { The error of } \\
\text { standard devia- } \\
\text { tion }\end{array}$ & $\begin{array}{l}\text { Significance lev- } \\
\text { el }\end{array}$ \\
\hline Combined & Teacher-made & 4.54 & 0.532 & 0.000 \\
\cline { 2 - 5 } & Traditional & 7.54 & 0.524 & 0.000 \\
\hline Teacher-made & Combined & -4.54 & 0.532 & 0.000 \\
\cline { 2 - 5 } & Traditional & 2.99 & 0.530 & 0.000 \\
\hline Traditional & Combined & -7.54 & 0.524 & 0.000 \\
& Teacher-made & -2.99 & 0.530 & 0.000 \\
& & & &
\end{tabular}

\section{Discussion}

The findings of this study showed that the teaching methods of the teacher-made concept map and combined have been effective on academic achievement. In general, in answer to the general question of this research, it can be concluded that the findings of the present study show that the presenting concept map education has a positive effect on increasing students' academic achievement scores in the course of thinking and media literacy. This result with the metaanalysis findings of nineteen studies shows that the overall concept map has a positive effect on both academic achievement and students' attitudes (Mesrabadi et al., 2009). In addition, the results of several studies show that using concept maps can have a positive effect on academic indicators (Taei, 2014) and (Eommiri, 2008) and (Jegede \& Alaiyemola, 1990) and (Huai, 1997) and (Fajonyomi, 2002). The results of the present study confirm the research findings of (Mesrabadi et al., 2005) and (Sakiyo \& Waziri, 2015) and (Mesrabadi et al., 2009) and (Kardan et al., 2015) in the field of the effect of concept map on academic achievement.

When educational materials are presented to students in the form of concept maps, all the features of meaningful verbal learning characteristics that are considered by David Ausubel are embedded in this type of education. Because conceptual maps represent content in a hierarchical way from whole to detailed, such as the pyramid structure of information in the mind and the relationships between concepts and subjects, (Miesrabadi \& Ostovar, 2009) emphasizes that one of the most effective ways to relate new material to the existing cognitive structure is using concept maps.

Furthermore, base $d$ on information processing theories, it can be expected that using concept maps will have a positive effect on the processes of memorization, storage and reminding of the contents. The implications of Paivio's dual code theory are clearer than the other two theories, i.e., triple memory and processing levels. According to Paivio's theory of dual coding, information is encoding verbally and visually in memory, if this encoding is done on a subject in both ways will improve memory processes. Concept maps present verbal material in the form of drawings that use both methods of encoding. According to Paivio's theory, it can be expected that using a concept map in learning and recalling material is more effective than presenting the material verbally (Paivio, 1991).

Furthermore, based on the Atkinson and Shiffrin's triple memory theory, the effectiveness of concept maps can be explained as follows: According to this theory, the main way to transfer 
content from short-term memory to long-term memory is to establish a connection between short-term memory and long-term memory that concepts map make it easier and clearer by showing the structures and connections between the contents. According to Craik and Lockhart theory of processing levels, it can be said that the use of concept maps, especially when preparing them, causes the content to be processed at a deeper level, in which case they will be stored longer and will be remembered faster and easier.

\section{Conclusion}

Metacognitive theory is another theoretical foundation that supports the effectiveness of the concept map as a teaching-learning tool. Based on the research results, it can be concluded that concept maps can be used as effective cognitive and metacognitive tools (Huai, 1997).

In summary, research in the field of concept map has shown that teaching with the help of concept map increases learning, retention and retrieval of information and this increases meaningful learning and academic achievement (Bardel \& Mahmoudi, 2019) and (Roth \& Roychoudhury, 1992) and (Taei, 2014) and (Ghanbari, 2014) and (Ashuri et al., 2014) and (Mesrabadi et al., 2009) and (Chen et al., 2019) and (Watson \& Barrella, 2016) and (Sakiyo \& Waziri, 2015) and (Novak \& Canas, 2008) and (Hall \& Donnell, 1996).

Therefore, according to the theoretical foundations that were discussed, it can be concluded that in most of the theories that have been presented in the field of school learning, we can find implications in the field of concept map effect. Ausubel's theory of verbal learning, Bronde theory, and existing theories of cognition and metacognition, and theories of news reporting are supportive. In addition, according to the consistence of the research findings and the results of the present study, it can be concluded that education based on concept map can have a positive effect on increasing the academic achievement of students.

\section{References}

Zeinalipour H. \& Zarei S. \& Iqbalo Zandinia Z. (2009), General and Academic Self-efficacy of Students and Its Relationship with Academic Performance, Journal of Educational Psychology Studies, 9(2): 28-13.

Fajonyomi M. (2002), Concept mapping, student's locus of control as gender as determination of igerians high school student'sachievement in biology, AfricanJournals Online, 2(10): 423-431.

Chen C. \& Huang C. \& Chou Y. (2019), Effects of augmented reality-based multidimensional concept maps on students' learning achievement, motivation and acceptance, Univ Access Inf Soc, 29(6): 69-78.

Erkman F. \& Canver A. \& Handesart Z. \& Borkan B. \& Sahan K. (2010), Influenceof perceived teacher acceptance, self-concept and school attitude on theacademic achievement of school-age children in Turkey, Cross culturalResearch, 44(3): 295-309.

Neuman A. \& Guterman O. (2016), Academic achievements and homeschooling-It all depends on the goals, Studies in Educational Evaluation, 5(1): 1-6.

Feldman D. \& Kubota M. (2015), Hope, self-efficacy, optimism, andacademic achievement: Distinguishing constructs and levels of specificity, 19(3): 149-170.

Safarzadeh Saharroomarashian F. (2015), The Relationship between Critical Thinking and Metacognition with Academic Success in Female Students, Quarterly Journal of Women and Culture, 15(7): 43-29

Bolin R. \& Pate M. \& McClintock J. (2017), The impact of alcohol and marijuana use on academic achievement among college students, Journal of Educational Leadership and Management, 19(4), 288-296.

Martin D. (1994), "Concept mapping as an aid to lesson planning: a longitudinal study", Journal of Elementary Science Education, 6(3): 18-30. 
Fraser K. \& Edwards J. (1985), "The effects of training in concept mapping on student achivemant in traditional classroom tests", Research in Science Education, 29(3): 159-169.

Mesrabadi J. \& Fathi Azar E. \& Ostvar N. (2005), Investigating the Effectiveness of Individual Presentation and Construction and Group Construction of Concept Maps as an Educational Strategy, Quarterly Journal of Educational Innovations, 13(8): 11-23.

Cañas A. \& Novak J. (2007), "Theoretical Origins of Concept Maps and How to Construct and Use Them", Reflecting Education: Fascinating cultural artifacts: multimodal (concept) mapping in teaching and learning: www.reflectingeducation.net/index.php/reflecting 3(November): pp. 29-42.

Okebukola P. \& Jegede J. (1989), "Cognitive preference and learning model as determinants of meaningful learning through concept mapping", Science Education, 7(1): 232-241.

Tsai C. (2000), "Relationships between student scientific epistemological beliefs and perceptions of constructivist learning environments", EducationalResearch, 4(2): 193-205.

MEsrabadi J. \& Hosseini Nasab D. \& Fathi Azar A. (2009), The Effect of Constructing and Presenting a Concept Map and Learning Style on Remembering and Problem Solving in Biology, Educational and Psychological Studies of Ferdowsi University of Mashhad, 10(3): 19-15.

Muijs D. \& Reynolds D. (2005), Effective teaching: evidence and practice, London: Journal of Educational Psychology Studies, 13(6): 175-187.

Fellows N. (1994), “A window into Thinking: Using student writing to understand conceptual change in science learning". Journal of Research in science Teaching, 3(1): 985-1001.

Taei L. (2014), Effectiveness of Problem Solving Education through Teaching-Learning Strategy of Concept Map on Academic Achievement of Shiraz High School Students in Mathematics, First International Conference on Psychology and Educational Sciences, Shiraz, Hakim Orfi Higher Institute of Science and Technology, 18(2): 47-60.

Ghanbari A. (2014), Evaluation of the Effectiveness of Concept Map Training on the Concepts of Chemical Bonding in High School Students, the first scientific conference on strategies for the development and promotion of science education in Iran, Galehdar, Galehdar Education Department, Galehdar Payame Noor University, 6(3): 119-185.

Ashuri J. \& Kajbaf M. \& Baqer M. \& Talebi H. (2014), The Effect of Conceptual Teaching Methods, Participatory and Traditional Learning on Motivation for Academic Achievement and Progress in Biology. Research in curriculum planning, 2(14): 63-73.

Jegede O. \& Alaiyemola F. (1990), "The effect of concept mapping on student", Journal of Technology andEducational Research, 1(2): 89-100.

Baldan P. \& Chatain T. \& Haar S. \& Konig B. (2010), "Unfolding-based diagnosis of systems with an evolving topology", Information and Computation, 208(10): 1169-1192.

Novak J. \& Canas A. (2008), " The Theory underlying concept maps and how to construct and use them", Technical report IHMC Cmaptools, 15(4): 69-75.

Kardan J. \& Hatami J. \& Fathi Azar I. (2015), The Effect of Concept Map on the Academic Achievement of High School Students in Physics, Quarterly Journal of New Educational Approaches, 11(1): 62-41.

Lee Y. \& Nelson D. (2005), "Viewing orVisualizing-Which Concept Map Strategy WorksBest on Problem-solving Performance?", BritishJournal of Educational Technology, 3(6): 193-203.

Hall R. \& Donnell A. (1996), "Cognitive and affective outcomes of learning from knowledgemaps", Contemporary Psychologist, 2(1): 94-101.

Jouzayi K. \& Sadi pour E. (2013), "Comprison the impact of scaffolding teaching method and traditional teaching method on academic motivation of high school second grade students in English lesson", Research in Curriculum planning, 10(9): 79-86.

Beck E. (2008), "Understanding Educational change", American Conference on the Learning paradigm, 21(3): 241-253.

Collins B. \& Robert N. (2020), “The Effectiveness of Concept Maps for Students' Learning and Retention”, APSA Preprints, 19(6): 198-209. 
Watson M. \& Barrella E. (2016), "Using Concept Maps to Explore the Impacts of a LearningCycle-Based Sustainability Module Implemented in Two Institutional Contexts", Journal of Professional Issues in Engineering Education and Practice, 14(2): 129-148.

Eommiri F. (2008), "The Educational Effects of Concept Map Applied to the Grammar Education", The Journal of Korean Language and Literature Education, 4(3): 105-136.

Sakiyo J. \& Waziri K. (2015), "Concept mapping strategy: An effective tool for improving students' academic achievement in biology", Journal of Education in Science, Environment and Health (JESEH), 2(1): 179-217.

Huai H. (1997), "Concept mapping in learning biology: Theoretical review oncognitive and learning styles", Journal of Interactive Learning Research, 8(4): 38-48.

Miesrabadi J. \& Ostovar N. (2009), The Effectiveness of a Concept Map on Students' Academic Achievement in Biology, Psychology and Physics, Journal of New Educational Thoughts, 5(1): 114-93.

Paivio A. (1991), "Building an organized knowledge base, Concept mapping \&achievement in secondary school physics", Journal of Research in ScienceTeaching, 2(7): 315-333.

Bardel M. \& Mahmoudi F. (2019), Comparison of the Effectiveness of Concept Map and Traditional Method on Students' Academic Achievement in Experimental Sciences, New Educational Thoughts, 16(1): 519-530.

Roth W. \& Roychoudhury H. (1992), "The social construction of scientific concepts or the concept map as conscription device and tool for social thinking in high school", Science Education, 76(6): 531-557.

Novak J. (1991), "Clarify with concept maps", The Science Teacher, 58(7): 45-59. 